\title{
Ghrelin Effects on the Circadian System of Mice
}

\author{
Paola C. Yanniellii, ${ }^{\dagger}{ }^{\dagger}$ Penny C. Molyneux, ${ }^{2}$ Mary E. Harrington, ${ }^{2}$ and Diego A. Golombek ${ }^{1}$ \\ ${ }^{1}$ Universidad Nacional de Quilmes/Consejo Nacional de Investigaciones Científicas y Técnicas, Bernal, 1876 Buenos Aires, Argentina, and ${ }^{2}$ Neuroscience \\ Program, Smith College, Northampton, Massachusetts 01063
}

The orexigenic peptide ghrelin stimulates both food intake and growth hormone release and is synthesized in the stomach and in hypothalamic areas involved in feeding control. The suprachiasmatic nuclei of the hypothalamus (SCN) control most circadian rhythms, although there is evidence that some oscillators, such as food-entrainable oscillators, can drive activity rhythms even after SCN ablation. Ghrelin levels exhibit a circadian rhythm and closely follow feeding schedules, making this peptide a putative candidate for food-related entraining signals. We examined the response of the SCN to ghrelin treatments in vitro, by means of electrophysiological and bioluminescence recordings, and in vivo, by assessing effects on the phase of locomotor activity rhythms. Ghrelin applied at circadian time 6 in vitro to cultured SCN slices induced an $\sim 3 \mathrm{~h}$ phase advance. In addition, ghrelin phase advanced the rhythm of PER2::LUC (Period2::Luciferase) expression in cultured SCN explants from $m P e r 2^{L u c}$ transgenic mice. In vivo, intraperitoneal administration of ghrelin or a synthetic analog, growth hormone-releasing protein-6 (GHRP-6), to ad libitum fed animals failed to alter circadian phase. When injected after $30 \mathrm{~h}$ of food deprivation, GHRP-6 induced a phase advance compared with saline-injected animals. These results indicate that ghrelin may play a role in the circadian system by exerting a direct action on the SCN and that the system as a whole may become sensitive to ghrelin and other feeding-related neuropeptides under conditions of food restriction.

Key words: ghrelin; phase shift; electrophysiology; bioluminescence; food entrainment; GHRP-6

\section{Introduction}

Biological rhythms in most organisms are driven by an extraordinary league of clocks, mastered by the suprachiasmatic nuclei (SCN) of the hypothalamus in mammals (Klein et al., 1991; Antle and Silver, 2005). Light is the most relevant cue for circadian entrainment, although nonphotic stimuli also function as Zeitgebers or time givers. Daily feeding can entrain free-running rhythms, both by acting on the SCN (Stephan, 1986; Abe et al., 1989; Mistlberger, 1993) and, as demonstrated in animals with SCN ablation, in an anatomically separate area called the foodentrainable oscillator (Holmes and Mistlberger, 2000; Stephan, 2002; Davidson, 2006). Hypocaloric feeding phase advances three circadian outputs in mice: locomotor activity rhythm, pineal melatonin, and SCN vasopressin, suggesting that metabolism is able to modulate circadian rhythmicity (Mendoza et al., 2005a). Behavioral and molecular studies indicate that the SCN can be entrained to food availability under different conditions (Stephan, 1986; Abe et al., 1989; Mistlberger,1993; Challet et al., 1996, 1997; Marchant and Mistlberger, 1997; Castillo et al., 2004; Mendoza et al., 2005b).

Received Sept. 8, 2006; revised Feb. 2, 2007; accepted Feb. 2, 2007.

This work was supported by Consejo Nacional de Investigaciones Científicas y Técnicas, Agencia Nacional de Promoción Científica y Tecnológica and Universidad Nacional de Quilmes (P.C.Y., D.A.G.), and National Science Foundation Grants 0423200 and 0234203 (M.E.H.). The assistance of María Juliana Leone and Patricia Agostino is gratefully acknowledged. This paper is dedicated to the memory of our dear colleague and friend Dr. Paola C Yannielli (1969-2006)

${ }^{\dagger}$ Deceased, Sept. 23, 2006.

Correspondence should be addressed to Dr. Diego Golombek, Universidad Nacional de Quilmes, Roque S. Peña 352 Bernal, 1876 Buenos Aires, Argentina. E-mail: dgolombek@unq.edu.ar.

DOI:10.1523/JNEUROSCI.3913-06.2007

Copyright $\odot 2007$ Society for Neuroscience $\quad$ 0270-6474/07/272890-06\$15.00/0
Besides the SCN, the arcuate nuclei (Mistlberger and Antle, 1999), the paraventricular nuclei (Kalra et al., 1999; Currie et al., 2005), the dorsomedial hypothalamus (Gooley et al., 2006; Landry et al., 2006), and the digestive system (Davidson et al., 2003) have also been suggested to be important for food entrainment.

An important substance associated with hunger is ghrelin, an orexigenic peptide identified as the endogenous ligand for the growth hormone $(\mathrm{GH})$ secretagogue receptor (Kojima et al., 1999). Ghrelin stimulates GH secretion and promotes wakefulness, weight gain, and adrenocorticotropic hormone and cortisol release in humans and rodents (Frieboes et al., 1995; Wren et al., 2000; Diano et al., 2006; Szentirmai et al., 2007). Peripheral ghrelin levels rise sharply before main meals and decrease once the animal has been fed, most strikingly under restricted feeding conditions (Sugino et al., 2002; Kalra et al., 2003; Bodosi et al., 2004). Under fasting conditions, plasma ghrelin peaks match the previous pattern of daily meals in humans (Natalucci et al., 2005). Peripheral ghrelin from the digestive system may reach the CNS to act as a potential feedback signal for the SCN (Banks et al., 2002; Li et al., 2006; Theander-Carrillo et al., 2006). Ghrelin may also be synthesized in the hypothalamus (for review, see Horvath et al., 2001). Ghrelin-immunoreactive neurons are present in the paraventricular, dorsomedial, ventromedial, and arcuate nuclei, areas important for circadian output (Cowley et al., 2003; Yi et al., 2006).

Contrary to the well documented effects of ghrelin on appetite, GH release (van der Lely et al., 2004) and the sleep-wake cycle (Weikel et al., 2003; Bodosi et al., 2004), little is known about the effects of ghrelin on circadian rhythms. As a peripheral and central hormone directly implicated in appetite and feeding- 
related activity, ghrelin is a good candidate signal for food entrainment. We combined electrophysiological recordings, bioluminescence detection, and in vivo behavioral measures to determine whether ghrelin acts on the circadian system of mice at the level of the SCN.

\section{Materials and Methods}

Animals

Mice used in all studies were adult animals derived from our in-house colonies. Experiments used male C57BL/6J mice or male and female $m P e r 2^{\text {Luc }}$ (mPeriod2 $\left.{ }^{\text {Luciferase }}\right)$ mice [bred from founders courtesy of Dr. Erik Herzog (Washington University, St. Louis, MO), derived from mice from the colony of Dr. J. Takahashi (Northwestern University, Evanston, IL)]. All mice were group housed in colony rooms under a $12 \mathrm{~h}$ light/dark (LD) cycle with food and water available ad libitum, unless otherwise noted.

Our research was in accordance with the Policies on the Use of Animals and Humans in Neuroscience Research (Society for Neuroscience, 1995) and with the regulations of the Institutional Animal Care and Use Committee of Smith College, an Association for Assessment and Accreditation of Laboratory Animal Care-certified facility.

\section{Peptides}

Ghrelin (rat, octanoylated) and des- $n$-octanoyl ghrelin (rat) were supplied by Global Peptides (Fort Collins, CO), and growth hormonereleasing protein-6 (GHRP-6) was obtained from Phoenix Pharmaceuticals (Belmont, CA).

\section{Electrophysiological studies}

For electrophysiological studies, Zeitgeber time was defined as ZT 12 being the projected time of lights off in the animal room. Adult male C57BL/6J mice were administered an overdose of halothane and decapitated during the light period of the $12 \mathrm{~h} \mathrm{LD}$ cycle. Hypothalamic slices $(500 \mu \mathrm{m})$ containing the SCN were placed in a gas-fluid interface slice chamber (Medical Systems BSC with Haas top), continuously bathed (1 $\mathrm{ml} / \mathrm{min}$ ) in artificial CSF (ACSF) containing the following (in mM): 125.2 $\mathrm{NaCl}, 3.8 \mathrm{KCl}, 1.2 \mathrm{KH}_{2} \mathrm{PO}_{4}, 1.8 \mathrm{CaCl}_{2}, 1 \mathrm{MgSO}_{4}, 24.8 \mathrm{NaHCO}_{3}$, and 10 glucose. ACSF, pH 7.4, was supplemented with an antibiotic (gentamicin, $50 \mathrm{mg} / \mathrm{L}$ ) and a fungicide (amphotericin, $2 \mathrm{mg} / \mathrm{L}$ ) and maintained at $34.5^{\circ} \mathrm{C}$. Warm, humidified $95 \%$ oxygen $/ 5 \%$ carbon dioxide was continuously provided. Ghrelin was applied as a microdrop (200 $\mu \mathrm{g}$ in $200 \mathrm{nl}$ of ACSF) directly onto the SCN.

Extracellular single-unit activity of SCN cells was detected with glass micropipette electrodes filled with ACSF, advanced through the slice using a hydraulic microdrive. The signal was further amplified and filtered and was continuously monitored by an oscilloscope and audio monitor. Firing rate was analyzed using data acquisition software and a customized program for calculation of descriptive statistics. A number of experiments in each condition were recorded "blind," and the person recording data had no knowledge of the treatment. One slice was recorded from each animal. Results were analyzed as described previously (Yannielli and Harrington, 2004) to determine the ZT of peak firing rate on the second day in vitro.

\section{mPER2::LUC bioluminescence}

For bioluminescence studies, we used adult male and female $m P e r 2^{L u c}$ mice, either homozygous or heterozygous for the gene (Yoo et al., 2004). Animals were killed during subjective day (between ZT2 and ZT10) by an overdose of halothane and decapitated, and brains were rapidly removed. Brains were placed in cold HBSS (Invitrogen, Carlsbad, CA), and coronal sections $(300 \mu \mathrm{m})$ were made on a vibratome. Hypothalamic sections were trimmed to the SCN and the optic chiasm and were placed on Millicell organotypic culture plate inserts (Millipore, Billerica, MA) in a $35 \mathrm{~mm}$ Petri dish with $1.2 \mathrm{ml}$ of culture media [DMEM (Fisher, Fairlawn, NJ) supplemented with $0.35 \mathrm{~g} / \mathrm{L}$ sodium bicarbonate, $10 \mathrm{~mm}$ HEPES, $\mathrm{pH}$ 7.2, B27 (2\%; Invitrogen), $0.1 \mathrm{~mm}$ luciferin (Promega, Madison, WI), and antibiotics (25 U/ml penicillin, $25 \mu \mathrm{g} / \mathrm{ml}$ streptomycin)] (for additional methodological details, see Yamazaki and Takahashi, 2005). Cultures were maintained at $35.8^{\circ} \mathrm{C}$, and bioluminescence was measured using a photomultiplier tube (Hamamatsu, as supplied by Actimetrics Lumicycle System, Evanston, IL). Samples were treated with $200 \mathrm{nl}$ of either ghrelin $(1 \mu \mathrm{g} / \mu \mathrm{l}$ in ACSF) or ACSF.

Tissue samples were monitored using an automated turntable device using an analysis program integrating photon counts over 1 min intervals with six such samples acquired each hour. The program fits a low-order polynomial to estimate the slowly changing baseline, which is then subtracted from the raw data. A sine wave with an exponential decay term is then fit to the data to estimate period. Phase is measured as the maximum of the baseline-subtracted data, after smoothing by a median smoother. $\chi^{2}$ periodograms indicate statistical significance of rhythmicity.

\section{Animal behavior}

Food intake test. Mice were placed individually in plastic cages, and food intake was calculated for the $24 \mathrm{~h}$ period before the treatment, by weighing the food pellets before and after this interval (day 0). At ZT 6 the next day (day 1), animals were injected intraperitoneally with ghrelin $(5 \mu \mathrm{g} /$ animal), GHRP-6 (50 $\mu \mathrm{g} / \mathrm{animal})$, or saline. Food pellets were then weighed every $30 \mathrm{~min}$.

Recording of locomotor activity. Mice were housed in individual cages equipped with running wheels, and their locomotor activity was measured using either Clocklab (Actimetrics, Evanston, IL) or software for data acquisition and analysis developed in our laboratory. After a minimum of $7 \mathrm{~d}$ entrainment to $12 \mathrm{~h} \mathrm{LD}$, animals were placed into constant darkness (DD). On day 5-7 of DD, animals received intraperitoneal injections of ghrelin, des- $n$-octanoyl ghrelin, GHRP-6, or saline at circadian time (CT) 6-8. After treatment, animals were left undisturbed to evaluate circadian phase shifts. Some animals were eventually treated again, following a counterbalanced design. Light intensities during the light and dark periods were set at 50 and $<0.05$ lux, respectively (dark experiments were performed under a dim red light source). The phase shifts in locomotor activity rhythm under DD conditions were calculated by two observers blind to experimental manipulations and were based on the distance between the two regression lines fit to daily onset of locomotor activity for at least $7 \mathrm{~d}$ before and after stimulation, excluding the $2 \mathrm{~d}$ immediately after treatment. CT 12 was defined as the time of activity onset. Ghrelin was administered at a dose chosen from previous studies in which intraperitoneal administration increased both food intake and plasma ghrelin concentrations ( $5 \mu \mathrm{g} /$ mouse or $1.6 \mathrm{nmol}$ GHRP-6: 50 $\mu \mathrm{g} /$ mouse) (Wren et al., 2000; Wang et al., 2002; Ruter et al., 2003). As a control, we used $5 \mu \mathrm{g} /$ mouse des- $n$-octanoyl ghrelin (Hosoda et al., 2000a), a compound that has been reported to have no endocrine effects on growth hormone receptors (Hosoda et al., 2000b).

Food deprivation schedule. These experiments were conducted using GHRP-6 as an analog of ghrelin. Animals kept under DD were treated as described previously, except that, on day 0 , food (but not water) was removed at CT 6 for $30 \mathrm{~h}$. Animals were injected intraperitoneally with GHRP-6 ( 5 or $50 \mu \mathrm{g} /$ mouse in $100 \mu \mathrm{l}$ saline) or $100 \mu \mathrm{l}$ saline at CT 6 of the next day (day 1). At CT 12 of day 1 , food was restored ad libitum as before. Phase shifts were calculated as stated above.

Data analysis. Group differences were statistically analyzed by Student's $t$ tests or ANOVA procedures when necessary. The criterion for statistical significance was $p<0.05$.

\section{Results}

\section{In vitro experiments}

Our first approach to study the effect of ghrelin on the circadian system of mice was conducted in vitro, by recording the electrical activity rhythm of coronal sections containing the SCN. Ghrelin treatment at ZT 6 on the first day in vitro induced a $3 \mathrm{~h}$ phase advance in the rhythm of spontaneous firing measured on the second day in vitro compared with ACSF-treated slices (ghrelintreated slices peak time, $3.6 \pm 0.1 \mathrm{~h} ; n=6$ ) (Fig. 1). The same effect was found previously in ghrelin-treated slices from hamsters (Yannielli et al., 2005). Ghrelin treatment at ZT 14 on the first day in vitro did not shift the phase of the firing rate rhythm recorded on the second day in vitro (peak time, $6.6 \pm 0.1 \mathrm{~h} ; n=4$ ) relative to ACSF-treated slices (peak time, $6.67 \pm 0.2 \mathrm{~h} ; n=5$ ). 
A. Control, $n=5$

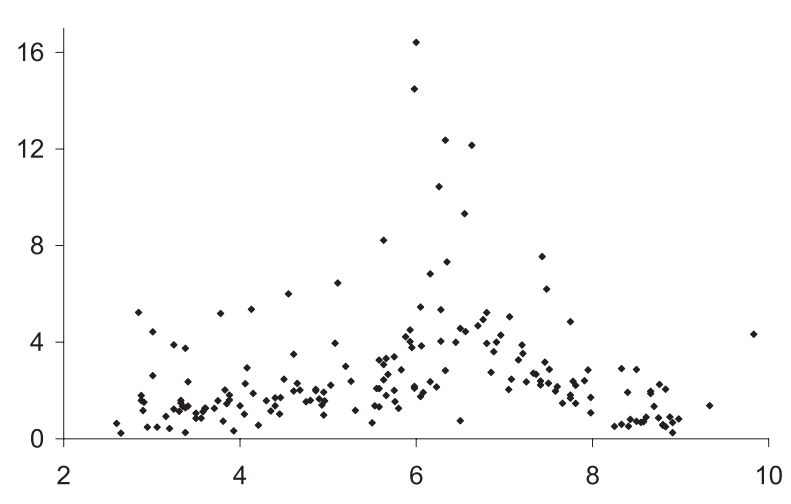

B. Ghrelin ZT6, n=6

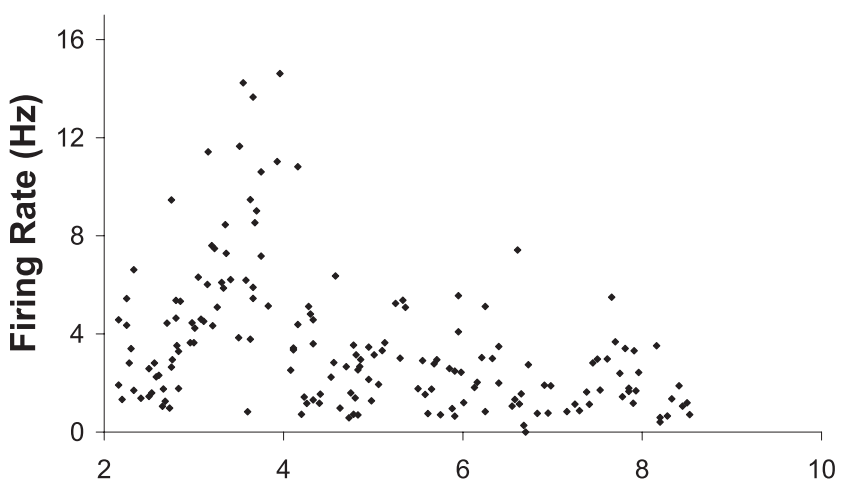

C. Ghrelin ZT14, n=4

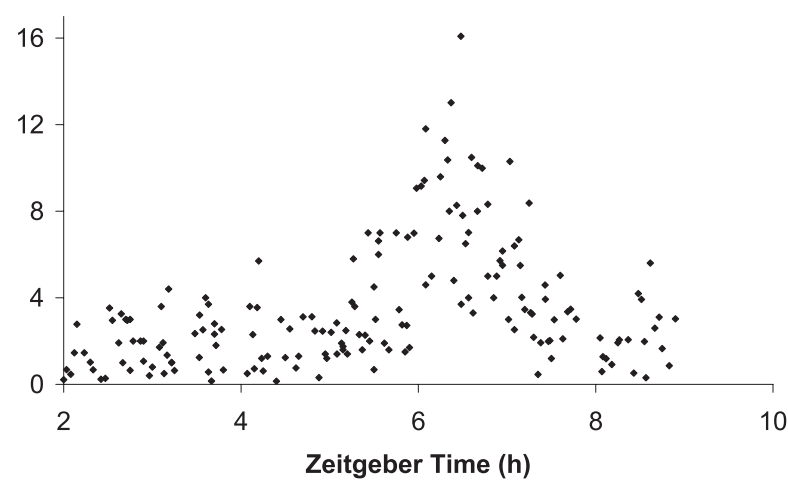

Figure 1. $\boldsymbol{A}-\boldsymbol{C}$, Results from electrophysiological experiments demonstrating phaseadvancing effects of ghrelin administered in the mid-subjective day $(\boldsymbol{B})$ when compared with control cases $(\boldsymbol{A})$ or samples in which ghrelin was administered in early subjective night (ZT 14; C). Each point indicates the average firing rate of an individual $\mathrm{SCN}$ neuron recorded from an SCN slice on day 2 in vitro. The $n$ indicates the number of SCN slices recorded in each condition. Zeitgeber time is relative to the animal's previous housing LD cycle, with ZT 12 defined as the time of lights off.

To further test the role of ghrelin in molecular timekeeping on intact SCNs, we recorded real-time circadian gene expression in transgenic mice with an mPER2::LUC fusion protein as a reporter. Recordings of bioluminescence from organotypic SCN cultures revealed precise circadian cycles of gene expression, as reported previously (Yoo et al., 2004). Ghrelin applied directly to the SCN cultures during the subjective day (relative to the time of peak expression considered as CT 11) significantly phase advanced the rhythm of PER2::LUC expression (Fig. 2 B). In contrast, the phase of ACSF-treated cultures remained unaffected (Fig. 2A). These experiments were performed at the appropriate CT once the SCN tissue was stabilized and clearly cycling; however, application of ghrelin at the time of dissection appeared to also advance the rhythms of SCN cultures (Fig. 2C). This effect was not statistically significant and was likely attributable to one outlier within the ghrelin-treated cultures (Fig. 2D).

\section{In vivo experiments}

Our data strongly suggest the possibility of a direct action of ghrelin on the SCN of mice. To evaluate the role of ghrelin on the circadian system in vivo and under physiological conditions, three separate experiments were performed. First, we tested the more conspicuous effect of peripheral ghrelin administration, i.e., to increase food intake. We found a strong effect of systemic ghrelin ( $5 \mu \mathrm{g} / \mathrm{animal})$ or GHRP-6 (50 $\mu \mathrm{g} / \mathrm{animal})$ on food intake $30 \mathrm{~min}$ after its injection, which was independent of the amount of food consumed in the previous $24 \mathrm{~h}$ (Fig. 3). Visual observations indicated that ghrelin or GHRP- 6 acted quickly (between 5 and 15 min after the injection) and that, at these doses, we saw no evident side effects, such as sedation or changes in locomotion levels.

Second, we tested ghrelin applied to ad libitum fed mice housed with running wheels. Ghrelin did not have any phaseshifting effect at CT 6 (12.2 $\pm 2.2 \mathrm{~min} ; n=8)$, although some animals did show a strong suppression of their wheel-running activity. In these cases, locomotor activity was restored within $1 \mathrm{~d}$ after the treatment without any significant changes in the phase. Administration of the control compound des- $n$-octanoyl ghrelin did not elicit significant phase shifts at CT $6(24.8 \pm 11 \mathrm{~min} ; n=6)$.

Finally, we tested the effect of GHRP-6, a synthetic and more accessible peptide with the same orexigenic effects as ghrelin (Lawrence et al., 2002). Injection of GHRP-6 did not alter phase when injected into ad libitum fed mice (Fig. 4). Under fooddeprivation conditions, conversely, $50 \mu \mathrm{g}$ (but not $5 \mu \mathrm{g}$ ) of GHRP-6 induced a significant phase advance of the free-running rhythm (Fig. 4). Almost all animals under food deprivation showed an increase in wheel-running activity after injection of GHRP-6 at CT 6.

\section{Discussion}

Our results demonstrate that ghrelin applied directly onto the $\mathrm{SCN}$ in the subjective day in vitro can phase advance circadian rhythms, similar to other previously described nonphotic stimuli. SCN-driven electrical activity rhythm was significantly phase advanced compared with ACSF-treated slices in our electrophysiological studies. This effect has also been observed in ghrelintreated slices from hamsters (Yannielli et al., 2005). Moreover, in the present work, we demonstrate that cycling of a PER2::LUC fusion protein that reflects an intrinsic component of the circadian clock machinery is also significantly phase advanced by ghrelin applied during subjective day on SCN explants. These data strongly suggest that there is a direct effect of ghrelin on the clock mechanism in the SCN. Supporting this, Zigman et al. (2006) reported that ghrelin receptor mRNA is strongly expressed in the mouse SCN. Thus, the present study suggests a direct phaseshifting effect of ghrelin on receptors in the SCN.

Interestingly, ghrelin or its analog GHRP-6 administered in vivo failed to induce any significant change in the phase of the wheel-running rhythms of mice under both continuous dark and ad libitum feeding conditions. However, a consistent effect of 
A.

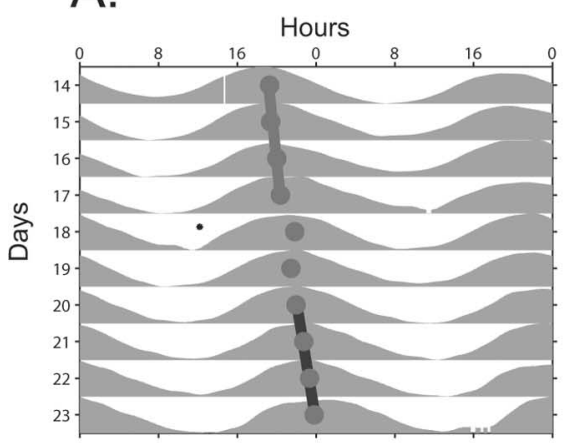

C.

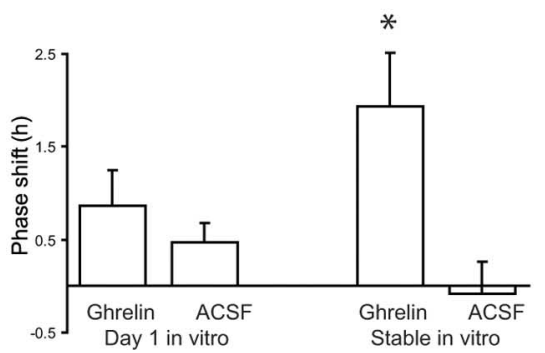

B.

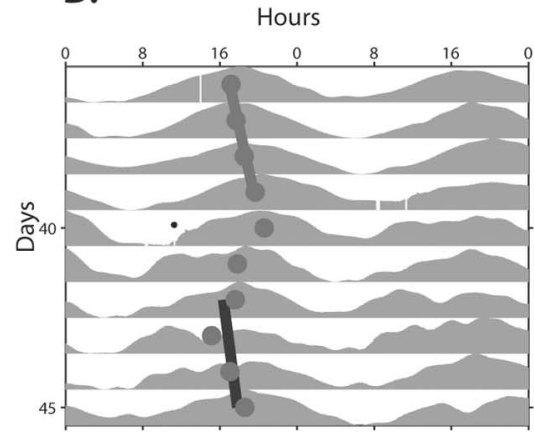

D.

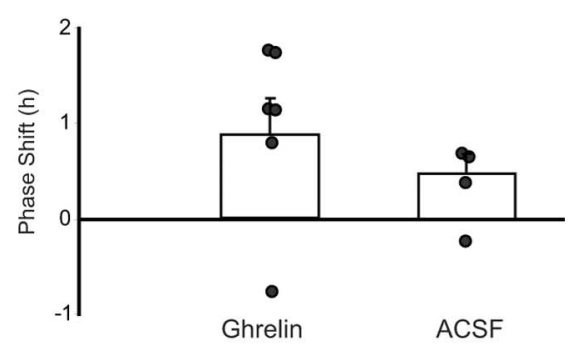

Figure 2. Results from mPER2::LUC bioluminescence experiments demonstrating the phase-advancing effects of ghrelin administered in the subjective day. $\boldsymbol{A}$, SCN bioluminescence rhythm with an ACSF application on day 18. $\boldsymbol{B}$, SCN sample with ghrelin application on day 40 (asterisk). After several days of transients, there is a phase advance in the acrophase of the rhythm. C, Summary of the phase shift results from applications of ghrelin or ACSF on either the day of dissection (Day 1 in vitro) or from established cycling SCN cultures (Stable in vitro). Asterisk indicates $p<0.01$. D, Phase shift measured from SCN cultures treated with either ghrelin or ACSF at time of dissection on day 1. Error bars show mean \pm SEM, and dots show peak time of each individual culture. Groups are not statistically different, but, if the one outlier is removed from the ghrelin-treated group, a $t$ test is significant $(p=0.01)$.

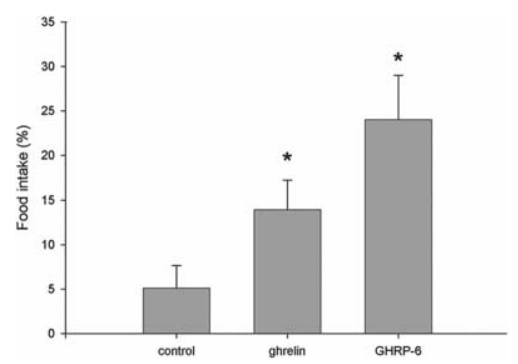

Figure 3. Ghrelin and GHRP- 6 stimulate feeding. Food intake was measured 60 min after injection with ghrelin, GHRP-6, or vehicle and is expressed as percentage of food intake in 60 min with respect to the previous $24 \mathrm{~h}$ food intake for that mouse. Mean \pm SEM is shown; $p<$ 0.05 , ANOVA with Dunnett's test versus control.

systemic administration of ghrelin was to completely or partially suppress wheel running after the injection, without affecting the rhythm parameters or wheel-running levels afterward, indicating a direct inhibitory effect of this peptide on locomotor activity (Tang-Christensen et al., 2004). When the experiment was repeated after a food-deprivation regimen (30 h total), GHRP-6 treatment induced a small phase advance and a brief period of up to $1 \mathrm{~h}$ of increased locomotor activity. The GHRP-6 phase shift could be mediated by the increased locomotor activity or reflect an increased sensitivity of the system to behavioral manipulations. Indeed, saline treatment in fasted animals yielded very variable results, which may also reflect the sensitivity of the system under the food-deprivation condition.

Alternatively, it seems plausible that the circadian system may

start to respond to food-related cues such as peripheral ghrelin administration only after other regularly potent and commanding cues are absent, namely, light and ad libitum food availability. Consistent with this hypothesis, a $48 \mathrm{~h}$ fast potentiates induction of c-Fos protein in the ventromedial arcuate after systemic administration of GHRP-6 (Luckman et al., 1999), suggesting that, in ad libitum fed animals, arcuate nuclei cells show a reduced sensitivity to endogenous growth hormone secretagogues or they are under the tonic inhibitory influences of other factors.

Although the mechanism explaining why food deprivation unmasks the phaseshifting capability of ghrelin in vivo is unclear, it is tempting to speculate that an upregulation of central receptors might be at least partially responsible for this effect. Indeed, feeding status affects not only ghrelin secretion but also the expression of its receptor in the CNS (Nogueiras et al., 2004; Sun et al., 2004; Tups et al., 2004). In particular, ghrelin receptor levels were increased eightfold in the rat hypothalamus after 48 h of fasting (Kim et al., 2003), indicating that there is a finely tuned regulation of ghrelin and its receptor contributing to energy balance mechanisms.

The SCN coordinates the timing of energy metabolism, including feeding and drinking rhythms and glucose and corticosterone secretion, among other metabolic signals. In this sense, it is reasonable to expect feedback from the periphery to the clock pacemaker, as happens with many other stimuli. There are several ways by which circulating ghrelin could affect hypothalamic areas. Ghrelin can reach the brain across the blood-brain barrier (Banks et al., 2002), with hypothalamic levels increased after peripheral injections of radiolabeled ghrelin (Diano et al., 2006). Ghrelin secreted by the stomach could eventually affect central sites via a vagal cholinergic efferent pathway (Date et al., 2002; Li et al., 2006). In this sense, the peak of circulating ghrelin in anticipation of main meal episodes could act on the circadian clock.

Primary hypothalamic targets of ghrelin are NPY/agoutirelated protein arcuate neurons, and feeding behaviors exerted by ghrelin are related to this area (Kamegai et al., 2000; Chen et al., 2004; Mondal et al., 2005). The arcuate is characterized by receptors for peripherally active hormones, including ghrelin (Cowley et al., 2003; Mondal et al., 2005). It has been reported that the blood-brain barrier border could actually lie at the area between the median eminence and the distal part of the arcuate, indicating that the proximal arcuate could be exposed to circulating neuroactive substances (Shaver et al., 1992). Recently, a reciprocal linkage between the ventromedial arcuate to the SCN was established by means of anterograde and retrograde tracing techniques (Yi et al., 2006). Thus, the fact that the SCN receives an input from the arcuate suggests at least an indirect communication between the general circulation and the SCN. Peripheral ghrelin administration rapidly alters synaptic organization of hypothalamic neural circuits underlying feeding (Pinto et al., 2004), suggesting that 
A.

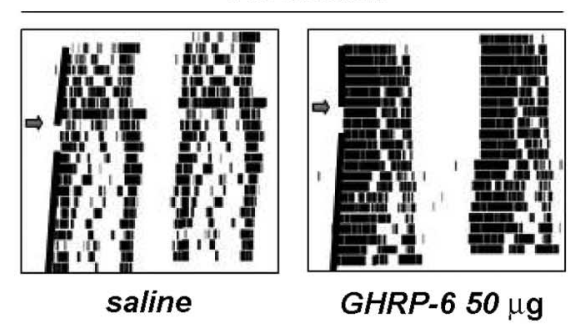

Food-deprived

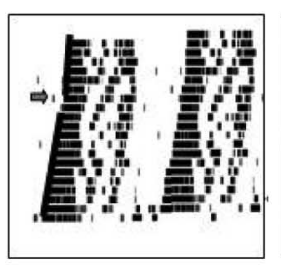

saline

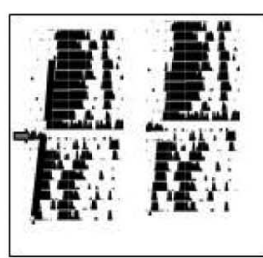

GHRP-6 $5 \mu \mathrm{g}$

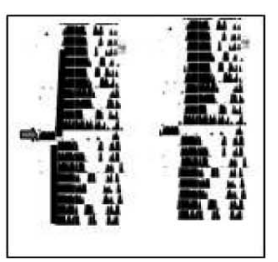

GHRP-6 $50 \mu \mathrm{g}$
B.

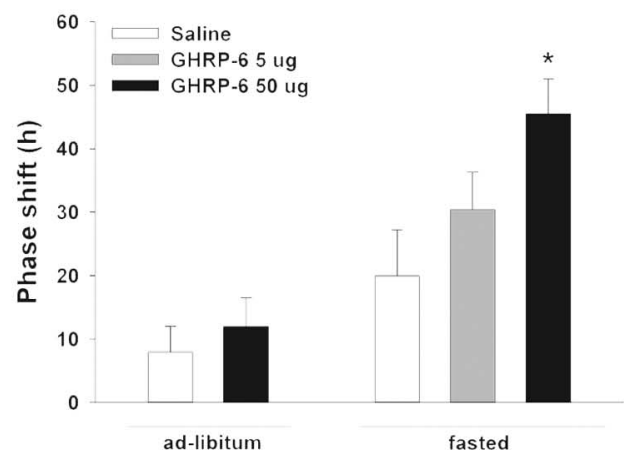

Figure 4. Ghrelin analog GHRP-6 induces phase advances of locomotor activity when applied at CT 6 after $24 \mathrm{~h}$ of food deprivation. $A$, Representative actograms of control or GHRP-6treated animals with or without food restriction. $\boldsymbol{B}$, Summary of phase shifts induced by GHRP-6 with or without $24 \mathrm{~h}$ of food deprivation ( ${ }^{*} p<0.05$, ANOVA followed by Dunnett's test vs saline control).

this peptide might induce rapid rewiring of circuits to allow entrainment to restricted feeding.

It has been reported that food restriction is able to phase shift clock gene expression in peripheral organs such as the liver, whereas the same genes at the level of the SCN pacemaker remain unaffected (Damiola et al., 2000). Recent studies have shown that SCN output might also be entrained by food restriction, although this depends on the caloric intake and the specific experimental design (Castillo et al., 2004; Mendoza et al., 2005a). It is possible that peripheral ghrelin may act as an intermediary between peripheral gastric activity and the master circadian clock (Dallman, 2003). Circulating ghrelin levels as well as gastric ghrelin mRNA expression have been reported to increase after fasting and decrease rapidly after refeeding (Tschop et al., 2000). Ghrelin stimulates eating when injected into the arcuate and paraventricular nuclei (Currie et al., 2005), and we have shown here that ghrelin resets the SCN clock when applied directly to SCN tissue during the subjective day. Moreover, gastric ghrelin has been found to affect gastric per 1 and per 2 expression, suggesting that it can also be considered as a signal regulating peripheral oscillators (Silver et al., 2005). The role of this peptide as a meal-related Zeitgeber remains to be established in well known models of foodentrainable oscillators. It would be interesting to see whether
SCN-lesioned animals can be entrained by daily ghrelin administration or whether ghrelin-deficient animals can be entrained by daily food restriction.

In summary, the present results support the hypothesis that metabolic cues such as ghrelin could influence circadian phase under conditions of restricted or no food availability, which may resemble natural conditions for most animals. Our experiments demonstrate that the isolated SCN can directly respond to ghrelin.

\section{References}

Abe H, Kida M, Tsuji K, Mano T (1989) Feeding cycles entrain circadian rhythms of locomotor activity in CS mice but not in C57BL/6J mice. Physiol Behav 45:397-401.

Antle MC, Silver R (2005) Orchestrating time: arrangements of the brain circadian clock. Trends Neurosci 28:145-151.

Banks WA, Tschop M, Robinson SM, Heiman ML (2002) Extent and direction of ghrelin transport across the blood-brain barrier is determined by its unique primary structure. J Pharmacol Exp Ther 302:822-827.

Bodosi B, Gardi J, Hajdu I, Szentirmai E, Obal Jr F, Krueger JM (2004) Rhythms of ghrelin, leptin, and sleep in rats: effects of the normal diurnal cycle, restricted feeding, and sleep deprivation. Am J Physiol Regul Integr Comp Physiol 287:R1071-R1079.

Castillo MR, Hochstetler KJ, Tavernier Jr RJ, Greene DM, Bult-Ito A (2004) Entrainment of the master circadian clock by scheduled feeding. Am J Physiol Regul Integr Comp Physiol 287:R551-R555.

Challet E, Malan A, Pevet P (1996) Daily hypocaloric feeding entrains circadian rhythms of wheel-running and body temperature in rats kept in constant darkness. Neurosci Lett 211:1-4.

Challet E, Pevet P, Vivien-Roels B, Malan A (1997) Phase-advanced daily rhythms of melatonin, body temperature, and locomotor activity in foodrestricted rats fed during daytime. J Biol Rhythms 12:65-79.

Chen HY, Trumbauer ME, Chen AS, Weingarth DT, Adams JR, Frazier EG, Shen Z, Marsh DJ, Feighner SD, Guan XM, Ye Z, Nargund RP, Smith RG, Van der Ploeg LH, Howard AD, MacNeil DJ, Qian S (2004) Orexigenic action of peripheral ghrelin is mediated by neuropeptide $\mathrm{Y}$ and agoutirelated protein. Endocrinology 145:2607-2612.

Cowley MA, Smith RG, Diano S, Tschop M, Pronchuk N, Grove KL, Strasburger J, Bidlingmaier M, Esterman M, Heiman ML, Garcia-Segura LM, Nillni EA, Mendez P, Low MJ, Sotonyi P, Friedman JM, Liu H, Pinto S, Colmers WF, Cone RD, Horvath TL (2003) The distribution and mechanism of action of ghrelin in the CNS demonstrates a novel hypothalamic circuit regulating energy homeostasis. Neuron 37:649-661.

Currie PJ, Mirza A, Fuld R, Park D, Vasselli JR (2005) Ghrelin is an orexigenic and metabolic signaling peptide in the arcuate and paraventricular nuclei. Am J Physiol Regul Integr Comp Physiol 289:R353-R358.

Dallman MF (2003) Filling the interstices: ghrelin neurons plug several holes in regulation of energy balance. Neuron 37:550-553.

Damiola F, Le Minh N, Preitner N, Kornmann B, Fleury-Olela F, Schibler U (2000) Restricted feeding uncouples circadian oscillators in peripheral tissues from the central pacemaker in the suprachiasmatic nucleus. Genes Dev 14:2950-2961.

Date Y, Murakami N, Toshinai K, Matsukura S, Niijima A, Matsuo H, Kangawa K, Nakazato M (2002) The role of the gastric afferent vagal nerve in ghrelin-induced feeding and growth hormone secretion in rats. Gastroenterology 123:1120-1128.

Davidson AJ (2006) Search for the feeding-entrainable circadian oscillator: A complex proposition. Am J Physiol Regul Integr Comp Physiol 290:R1524-R1526.

Davidson AJ, Poole AS, Yamazaki S, Menaker M (2003) Is the foodentrainable circadian oscillator in the digestive system? Genes Brain Behav 2:32-39.

Diano S, Farr SA, Benoit SC, McNay EC, da Silva I, Horvath B, Gaskin FS, Nonaka N, Jaeger LB, Banks WA, Morley JE, Pinto S, Sherwin RS, Xu L, Yamada KA, Sleeman MW, Tschop MH, Horvath TL (2006) Ghrelin controls hippocampal spine synapse density and memory performance. Nat Neurosci 9:381-388.

Frieboes RM, Murck H, Maier P, Schier T, Holsboer F, Steiger A (1995) Growth hormone-releasing peptide- 6 stimulates sleep, growth hormone, ACTH and cortisol release in normal man. Neuroendocrinology 61:584-589. 
Gooley JJ, Schomer A, Saper CB (2006) The dorsomedial hypothalamic nucleus is critical for the expression of food-entrainable circadian rhythms. Nat Neurosci 9:398-407.

Holmes MM, Mistlberger RE (2000) Food anticipatory activity and photic entrainment in food-restricted BALB/c mice. Physiol Behav 68:655-666.

Horvath TL, Diano S, Sotonyi P, Heiman M, Tschop M (2001) Minireview: ghrelin and the regulation of energy balance-a hypothalamic perspective. Endocrinology 142:4163-4169.

Hosoda H, Kojima M, Matsuo H, Kangawa K (2000a) Purification and characterization of rat des-Gln14-ghrelin, a second endogenous ligand for the growth hormone secretagogue receptor. J Biol Chem 275:21995-22000.

Hosoda H, Kojima M, Matsuo H, Kangawa K (2000b) Ghrelin and des-acyl ghrelin: two major forms of rat ghrelin peptide in gastrointestinal tissue. Biochem Biophys Res Commun 279:909-913.

Kalra SP, Dube MG, Pu S, Xu B, Horvath TL, Kalra PS (1999) Interacting appetite-regulating pathways in the hypothalamic regulation of body weight. Endocr Rev 20:68-100.

Kalra SP, Bagnasco M, Otukonyong EE, Dube MG, Kalra PS (2003) Rhythmic, reciprocal ghrelin and leptin signaling: new insight in the development of obesity. Regul Pept 111:1-11.

Kamegai J, Tamura H, Shimizu T, Ishii S, Sugihara H, Wakabayashi I (2000) Central effect of ghrelin, an endogenous growth hormone secretagogue, on hypothalamic peptide gene expression. Endocrinology 141:4797-4800.

Kim MS, Yoon CY, Park KH, Shin CS, Park KS, Kim SY, Cho BY, Lee HK (2003) Changes in ghrelin and ghrelin receptor expression according to feeding status. NeuroReport 14:1317-1320.

Klein DC, Moore RY, Reppert SM (1991) Suprachiasmatic nucleus: the mind's clock. New York: Oxford UP.

Kojima H, Sakamoto J, Yasue M (1999) Circadian rhythm-modulated chemotherapy with high dose 5 -fluorouracil against gastrointestinal cancers: evaluation and case report. Nagoya J Med Sci 62:29-38.

Landry GJ, Simon MM, Webb IC, Mistlberger RE (2006) Persistence of a behavioral food-anticipatory circadian rhythm following dorsomedial hypothalamic ablation in rats. Am J Physiol Regul Integr Comp Physiol 290:R1527-R1534.

Lawrence CB, Snape AC, Baudoin FM, Luckman SM (2002) Acute central ghrelin and GH secretagogues induce feeding and activate brain appetite centers. Endocrinology 143:155-162.

Li Y, Wu X, Zhao Y, Chen S, Owyang C (2006) Ghrelin acts on the dorsal vagal complex to stimulate pancreatic protein secretion. Am J Physiol Gastrointest Liver Physiol 290:G1350-G1358.

Luckman SM, Rosenzweig I, Dickson SL (1999) Activation of arcuate nucleus neurons by systemic administration of leptin and growth hormonereleasing peptide- 6 in normal and fasted rats. Neuroendocrinology 70:93-100.

Marchant EG, Mistlberger RE (1997) Anticipation and entrainment to feeding time in intact and SCN-ablated C57BL/6j mice. Brain Res 765:273-282.

Mendoza J, Angeles-Castellanos M, Escobar C (2005a) A daily palatable meal without food deprivation entrains the suprachiasmatic nucleus of rats. Eur J Neurosci 22:2855-2862.

Mendoza J, Graff C, Dardente H, Pevet P, Challet E (2005b) Feeding cues alter clock gene oscillations and photic responses in the suprachiasmatic nuclei of mice exposed to a light/dark cycle. J Neurosci 25:1514-1522.

Mistlberger RE (1993) Effects of scheduled food and water access on circadian rhythms of hamsters in constant light, dark, and light:dark. Physiol Behav 53:509-516

Mistlberger RE, Antle MC (1999) Neonatal monosodium glutamate alters circadian organization of feeding, food anticipatory activity and photic masking in the rat. Brain Res 842:73-83.

Mondal MS, Date Y, Yamaguchi H, Toshinai K, Tsuruta T, Kangawa K, Nakazato M (2005) Identification of ghrelin and its receptor in neurons of the rat arcuate nucleus. Regul Pept 126:55-59.

Natalucci G, Riedl S, Gleiss A, Zidek T, Frisch H (2005) Spontaneous 24-h ghrelin secretion pattern in fasting subjects: maintenance of a mealrelated pattern. Eur J Endocrinol 152:845-850.

Nogueiras R, Tovar S, Mitchell SE, Rayner DV, Archer ZA, Dieguez C, Williams LM (2004) Regulation of growth hormone secretagogue receptor gene expression in the arcuate nuclei of the rat by leptin and ghrelin. Diabetes 53:2552-2558.

Pinto S, Roseberry AG, Liu H, Diano S, Shanabrough M, Cai X, Friedman JM,
Horvath TL (2004) Rapid rewiring of arcuate nucleus feeding circuits by leptin. Science 304:110-115.

Ruter J, Kobelt P, Tebbe JJ, Avsar Y, Veh R, Wang L, Klapp BF, Wiedenmann B, Tache Y, Monnikes H (2003) Intraperitoneal injection of ghrelin induces fos expression in the paraventricular nucleus of the hypothalamus in rats. Brain Res 991:26-33.

Shaver SW, Pang JJ, Wainman DS, Wall KM, Gross PM (1992) Morphology and function of capillary networks in subregions of the rat tuber cinereum. Cell Tissue Res 267:437-448.

Silver R, Hoque N, LeSauter J (2005) Discovery of a putative food anticipatory circadian clock. Soc Neurosci Abstr 31:60.10.

Stephan FK (1986) Interaction between light- and feeding-entrainable circadian rhythms in the rat. Physiol Behav 38:127-133.

Stephan FK (2002) The "other" circadian system: food as a zeitgeber. J Biol Rhythms 17:284-292.

Sugino T, Hasegawa Y, Kikkawa Y, Yamaura J, Yamagishi M, Kurose Y, Kojima M, Kangawa K, Terashima Y (2002) A transient ghrelin surge occurs just before feeding in a scheduled meal-fed sheep. Biochem Biophys Res Commun 295:255-260.

Sun Y, Wang P, Zheng H, Smith RG (2004) Ghrelin stimulation of growth hormone release and appetite is mediated through the growth hormone secretagogue receptor. Proc Natl Acad Sci USA 101:4679-4684.

Szentirmai E, Kapas L, Krueger JM (2007) Ghrelin microinjection into forebrain sites induces wakefulness and feeding in rats. Am J Physiol Regul Integr Comp Physiol 292:R575-R585.

Tang-Christensen M, Vrang N, Ortmann S, Bidlingmaier M, Horvath TL, Tschop M (2004) Central administration of ghrelin and agouti-related protein (83-132) increases food intake and decreases spontaneous locomotor activity in rats. Endocrinology 145:4645-4652.

Theander-Carrillo C, Wiedmer P, Cettour-Rose P, Nogueiras R, Perez-Tilve D, Pfluger P, Castaneda TR, Muzzin P, Schurmann A, Szanto I, Tschop MH, Rohner-Jeanrenaud F (2006) Ghrelin action in the brain controls adipocyte metabolism. J Clin Invest 116:1983-1993.

Tschop M, Smiley DL, Heiman ML (2000) Ghrelin induces adiposity in rodents. Nature 407:908-913.

Tups A, Helwig M, Khorooshi RM, Archer ZA, Klingenspor M, Mercer JG (2004) Circulating ghrelin levels and central ghrelin receptor expression are elevated in response to food deprivation in a seasonal mammal ( $P$ hodopus sungorus). J Neuroendocrinol 16:922-928.

van der Lely AJ, Tschop M, Heiman ML, Ghigo E (2004) Biological, physiological, pathophysiological, and pharmacological aspects of ghrelin. Endocr Rev 25:426-457.

Wang L, Saint-Pierre DH, Tache Y (2002) Peripheral ghrelin selectively increases fos expression in neuropeptide Y-synthesizing neurons in mouse hypothalamic arcuate nucleus. Neurosci Lett 325:47-51.

Weikel JC, Wichniak A, Ising M, Brunner H, Friess E, Held K, Mathias S, Schmid DA, Uhr M, Steiger A (2003) Ghrelin promotes slow-wave sleep in humans. Am J Physiol Endocrinol Metab 284:E407-E415.

Wren AM, Small CJ, Ward HL, Murphy KG, Dakin CL, Taheri S, Kennedy AR, Roberts GH, Morgan DG, Ghatei MA, Bloom SR (2000) The novel hypothalamic peptide ghrelin stimulates food intake and growth hormone secretion. Endocrinology 141:4325-4328.

Yamazaki S, Takahashi JS (2005) Real-time luminescence reporting of circadian gene expression in mammals. Methods Enzymol 393:288-301.

Yannielli P, Harrington ME (2004) Let there be "more" light: enhancement of light actions on the circadian system through non-photic pathways Prog Neurobiol 74:59-76.

Yannielli PC, Harrington ME, Golombek DA (2005) Ghrelin: it's time to eat; effects of a novel feeding-related peptide on the circadian system. The Eighth Latin American Symposium on Chronobiology, Cordoba, Argentina, October.

Yi CX, van der Vliet J, Dai J, Yin G, Ru L, Buijs RM (2006) Ventromedial arcuate nucleus communicates peripheral metabolic information to the suprachiasmatic nucleus. Endocrinology 147:283-294.

Yoo SH, Yamazaki S, Lowrey PL, Shimomura K, Ko CH, Buhr ED, Siepka SM, Hong HK, Oh WJ, Yoo OJ, Menaker M, Takahashi JS (2004) PERIOD2::LUCIFERASE real-time reporting of circadian dynamics reveals persistent circadian oscillations in mouse peripheral tissues. Proc Natl Acad Sci USA 101:5339-5346.

Zigman JM, Jones JE, Lee CE, Saper CB, Elmquist JK (2006) Expression of ghrelin receptor mRNA in the rat and the mouse brain. J Comp Neurol 494:528-548. 